\title{
DERIVATION IN A WORD-BASED MORPHOLOGY: ON THE ORIGIN OF OLD ENGLISH VERBS OF PERCEPTION, COGNITION AND EMOTION
}

\section{INTRODUCTION}

This paper deals with some methodological and theoretical issues raised by diachronic lexical morphology (Pena 2008; Trips 2009). More exactly, in this paper I am going to describe the process of lexicalization in the grammaticalization of a selection of Old English causative verbs through the analysis of some of the different strategies for the expression of causation in three different lexical domains: PHYSICAL PERCEPTION, COGNITION and EMOTION. I will argue here that speakers can express relative measures of causation and that these grammatical variations are clearly reflected in the verb's lexical strata (Giegerich 1999: 87-88). Furthermore, I will describe some of the different ways synchronic patterns of morphological variation are to be related to diachronic processes of lexical formation, in order to show the relationship between the form and the meaning of this set of words.

My first aim will be to identify some of the different ways the grammatical parameter of causation finds a systematic correspondence on the syntax of the Old English verb, acting as a filter that accepts certain morphological patterns while blocking others. Furthermore, I will try to show that the strategies used in OE for the expression of causation can vary from one lexical domain to another. This implies that whereas all the predicates from the same lexical domain follow the same set of derivational processes, very significant differences can be detected when predicates from different domains are analyzed. In doing so, I want to show the existence of different grammars of causation, which broadly speaking correspond to the different degrees of causativity each predicate can attain.

\section{THE 'CAUSATION IS FORCED MOTION' METAPHOR}

Causation is a basic human concept. However, this does not imply that causation is an undecomposable primitive. Lakoff and Johnson (1999) state that human beings interpret the concept of CAUSE through conceptual metaphors, and many of these metaphors are related to MOTION. If, for example, object A moves towards object B setting it in motion, we assume that, without object A's movement, object B would have remained in its original position. The later extension of this understanding of causation to other domains, physical or abstract, implies a change towards the general identification between CAUSATION and FORCED MOTION. According to Lakoff and

\footnotetext{
*Author's address: Universidad de Castilla-La Mancha, Facultad de Letras, Filología Moderna, Avda. de Camilo José Cela s/n, 3071 Ciudad Real, España. Email: JavierEnrique.Diaz@uclm.es
} 
Johnson (2003: 69-70), causation is best understood as a cluster of components that form a gestalt:

We can see this most clearly in infants. Piaget has hypothesized that infants first learn about causation by realizing that they can directly manipulate objects around them-pull off their blankets, throw their bottles, drop toys. There is, in fact, a stage in which infants seem to "practice« these manipulations, e.g., they repeatedly drop their spoons. Such direct manipulations, even on the part of infants, involve certain shared features that characterize the notion of direct causation that is so integral a part of our constant everyday functioning in our environment-as when we flip light switches, button our shirts, open doors, etc. Though each of these actions is different, the over-whelming proportion of them share features of what we may call a »prototypical« or »paradigmatic« case of direct causation.

The underlying metaphor CAUSATION IS FORCED MOTION and its reflections in the derivational morphology of Proto-Germanic have been described in Díaz Vera (2000). In that paper, I argued that two of the three basic derivational patterns used by speakers of Primitive Old English (and other ancient Germanic languages) in order to derive causative verbs from non-causative ones are based on the combination of the corresponding lexical root (normally a noun) plus the formative $* / j \alpha /$. Furthermore, it is argued that this formative was originally used in order to derive agents from nouns (Lowe 1972: 215-215), as in the following examples:

PrGmc *herd- 'herd' + *j $\alpha->$ PrGmc *herdj $\alpha->$ OE hierde 'a keeper of a herd; someone who guides a herd'

PrGmc *do:m- 'a law, statute' + *j $\alpha->$ PrGmc *do:mj $\alpha>$ OE dēma 'a judge, arbiter, ruler; someone who administers law'

According to Pokorny (1959-69: 1.293), the ultimate origins of this Germanic suffix are to be found in the Indo-European verb */ei-/, with the meaning 'to cause something to move', illustrated by the Greek verb $\varepsilon 1 \mu \mathrm{l}$ 'to put in motion', which came to express 'motion in the future' in Attic and in Ionian (Liddell and Scott 1968: 489). In the examples above, the causative character of this formative is clear in the first example (OE herde 'someone who guides a herd') and, more figuratively, in the second one (OE dèma 'someone who administers law').

This derivational morpheme is also found with verbs expressing motion, as in the case of the Primitive OE weak verb *du:f-j $\alpha-n$ (OE dỹfan) 'to immerse, to cause something to move by diving', derived from the strong verb *du:fon (OE düfan) 'to dive'. This basic construction reflects a situation where a causer (i.e. the subject/agent) has a direct influence on the causee (ie. the object), which will change its position due to the causer's action. Furthermore, the rapid expansion of this derivational morpheme to other verbs from different lexical domains, both physical and abstract, and to nouns referring to different bodily organs (both external and internal) implied the develop- 
ment of a brand-new morphological category of verbs, normally known as 'weak verbs', and the progressive demise of the ablaut system inherited from Indo-European.

\title{
3. THE FORMATIVE *JA- COMBINED WITH NOUNS FOR EXTERNAL BOD- ILY ORGANS
}

Most Old English verbs of physical perception are denominal, that is, they are derived from the noun of the corresponding bodily organ, to which the formative */j $\alpha$ / 'to (cause to) move' is added. This is especially true for the following set of verbs of HEARING, SMELLING, TOUCHING and TASTING:

\author{
PrGmc * $\alpha$ uz- 'ear' + *j $\alpha->$ PrGmc *houzj $\alpha$ n- > OE hieran 'to hear' \\ PrGmc *n $\alpha s-$ 'nose' + *j $\alpha->$ PrGmc *n $\alpha$ sj $\alpha \mathrm{n}>\mathrm{OE}$ *ncesian $>$ ME nese 'to smell' \\ PrGmc *fo:1- 'hand, palm' + *j $\alpha->$ PrGmc *fo:lj $\alpha$ n- > OE félan 'to touch' \\ PrGmc *beuk- 'belly, body, trunk' + *j $\alpha->$ PrGmc *beurj $\alpha \mathrm{n}>$ OE byrgan 'to taste'
}

Only in the case of Old English verbs expressing SEEING, I have not been able to find illustrations of this derivational pattern. However, the OE verb scéawian 'to look', which derives from PrGmc *sk $\alpha$ wo:j $\alpha$ n (Orel 2003: 337), a certain degree of phonetic similitude with the noun for the corresponding sensory organ (PrGmc * $\alpha$ ug- > OE éage 'eye') can be detected.

In this second folk model of causation, we have a situation where a causer (i.e. the entity from which the physical sensation emanates) has a direct influence on the causee (ie. the corresponding external organ in the perceiver's body), which will change its form or texture due to the causer's action. This interpretation is fully coherent with the ancient seal-in-wax metaphor (Carruthers 1990: 21-30), according to which the act of perceiving produces a change in the perceiver; this change can be material (as in the case of TOUCHING) or spiritual (as in the other four cases). As Carruthers (1990: 70-71) puts it:

What the eye takes from the object via air and light is its 'formal' aspect but not its 'material' one, and this aspect causes the eye to change in the sensation we call 'sight'. The change in the eye occurs in the same manner in which phantasms are recorded in memory.

\section{THE FORMATIVE *JA- COMBINED WITH NOUNS FOR INTERNAL BODI- LY ORGANS}

The development of causative verbs of FEELING follows the morphological pattern described above for verbs of PHYSICAL PERCEPTION. However, verbs of FEELING are derived from nouns referring to the internal organ that is considered the see of each feeling in Anglo-Saxon folk beliefs. This is the case of OE heorte 'heart', which is considered the see of courage and fierceness: 
PrGmc *hert- 'heart' + *j $\alpha->$ PrGmc *hertjon- > OE hiertan 'to cause to have courage, to encourage'

This construction triggers a third folk model of causation as possession, where a causer (i.e. the entity from which the emotion emanates) takes hold of the causee (ie. the corresponding internal organ in the experiencer's body), which will change its ownership due to the causer's action. In turn, possession can be conceptualized in terms of location, so that something (an emotion) is in a certain place (a bodily organ). Similarly, we have in Old English the following verb:

PrGmc *mun- 'mind' + *-j $\alpha->$ PrGmc *munj $\alpha$ - > OE gemynan 'to cause to remember, to reminisce'

PrGmc *man- 'mind' + *-j $\alpha->$ PrGmc *manj $\alpha$ n- > OE gemanian 'to cause to remember, to reminisce'

Differently to thought (Ide *tang- > OE Jyncan), the mind (Ide * men- > OE munan) was related to a concrete bodily organ (either the heart or the brain). Our evidence form Old English and other Germanic languages clearly indicates that whereas memory was considered a function of a bodily organ, thinking was metaphorically mapped on the more abstract area of FEELING.

As for verbs of EMOTIONS, OE lufian 'to love' illustrates the construction described in this paper:

PrGmc *lißr- 'liver' + *o-j $\alpha->$ PrGmc *lußoj $\alpha$ n- > OE lufian 'to cause to feel love, affection'

Differently to the other Old English verbs described here, OE lufian is a Class II weak verb, which is composed of deverbal and denominal verbs with what is normally known as an intensive or iterative sense. From a chronological point of view, these verbs are relatively newer than Class I weak verbs, as reflected by the fact that their root vowels did not undergo the effects of /i/-Umlaut (Görlach 1997: 84). It has been suggested that causativity and intensive/iterative are two aspects of one original morpheme as, for example, in Indo-European (where both are expressed by the same suffix */ei-/; Lehmann 1993: 168), in Old Chinese (Schuessler 2007: 19) and in Amerindian languages (Broadwell 1997). Comrie (1985: 330) hypothesizes that this fact may be related to the "intensity (force) that is often implied in forcing someone to do something."

Causative verbs expressing more abstract emotions, such as sadness, grief, repent or pleasure, do not have a clear identification with a concrete bodily organ. Consequently, rather than from a noun referring to a bodily organ, the corresponding verbs are derived from the name of each emotion, as can be seen from the following examples:

PrGmc * $\alpha \mathrm{gl}$ - 'sadness' + *-j $\alpha->$ PrGmc * $\alpha \mathrm{glj} \alpha \mathrm{n}->\mathrm{OE}$ eglan 'to cause to feel sadness, affliction' 
PrGmc *lust- 'pleasure' + *-j $\alpha->$ PrGmc *lustj $\alpha$ - > OE lystan 'to cause to feel pleasure'

PrGmc *sk $\alpha \mathrm{m}$ - 'shame' + *-j $\alpha->$ PrGmc *sk $\alpha$ mj $\alpha$ n- > OE scéamian 'to cause to feel shame'

PrGmc *hrew- 'regret' + *-j $\alpha->$ PrGmc *hrewj $\alpha$ n- > OE hreowian 'to cause to feel regret, repentance'

\section{CONCLUSIONS}

In this brief analysis I have tried to show the following:

1. The basic causative morpheme *-j $\alpha$-, with the meaning 'to cause to move', was used to derive a whole new verbal class in Old English.

2. However, when applied to verbs of PERCEPTION, FEELING and EMOTION, the folk model of cause that underlies these constructions seems to see the world in terms of the naturalness of events, rather than in terms of causation proper.

3. In the case of PERCEPTION verbs, the causee corresponds to a sensory organ (nose, ears, stomach or skin), which undergoes a change (physical or abstract) in its form as a consequence of direct contact with the cause, which corresponds to the stimulus.

4. Whereas verbs of cognition (such as OE gemynan) follow a similar schema, the conceptualization represented by some Old English verbs of emotion combine causativity and iteration meanings. The emotion emanates directly from the bodily organ (as in the case of OE hiertan and lufian), changing its substance and causing the person to react.

\section{References}

BROADWELL, George A. (1997) "When causative means 'intensive'." Presented at the Society for the Study of the Indigenous Languages of the Americas summer meeting, Ithaca, NY July 15, 1997.

CARRUTHERS, MARY (1990) The Book of Memory: A Study of Memory in Medieval Culture. Cambridge: Cambridge University Press.

COETSEM, Frans van/Herbert L. KUFNER (eds) (1972) Towards a Grammar of ProtoGermanic. Berlin: Mouton de Gruyter.

COMRIE, Bernard (1985) "Causative verb formation and other verb-deriving morphology." In T. Shopen (ed.), 303-345.

DÍAZ VERA, Javier (2000) "The development of causation in Old English and its interaction with lexical and syntactic diachronic processes." Cuaderno de Investigaciones Filológicas 26, $17-38$.

GIEGERICH, Heinz (1999) Lexical Strata in English: Morphological Causes, Phonological Effects. Cambridge: Cambridge University Press.

GÖRLACH, Manfred (1997) The Linguistic History of English: An Introduction. London: Palgrave. LAKOFF, George/Mark JOHNSON (1999) Philosophy in the Flesh. Chicago: University of Chicago Press. 
LAKOFF, George/Mark JOHNSON (2003) Metaphors We Live By. Chicago: University of Chicago Press.

LEHMANN, Winfred, P (1993) Theoretical Bases of Indo-European Linguistics. London: Routledge LIDDELL, Henry George/Robert SCOTT (1968) Greek-English lexicon. Oxford: Clarendon.

LOWE, Pardee Jr (1972) “Germanic word formation.” In: F. van Coetsem/H.L. Kufner (eds), 211-238.

OREL, Vladimir (2003) A Handbook of Germanic Etymology. Leiden7Boston: Brill.

PENA, Jesús (2008) "El cambio morfológico en el interior de las series de derivación." Revista de Investigación Lingüística 11, 233-248.

POKORNY, Julius (1959-69) Indogermanische Etymologisches Wörterbuch. Bern/Münich: Francke Verlag.

SCHUESSLER, Alex (2007) ABC Etymological Dictionary of Old Chinese. Honolulu: University of Hawai'i Press.

SHOPEN, Timothy (ed) (1985) Language typology and syntactic description. Cambridge: Cambridge University Press.

TRIPS, Carola (2009) Lexical Semantics and Diachronic Morphology - The Development of-hood, -dom and -ship in the History of English (Linguistische Arbeiten 527). Tübinegen: Max Niemeyer Verlag.

\section{Abstract \\ DERIVATION IN A WORD-BASED MORPHOLOGY: ON THE ORIGIN OF OLD ENGLISH VERBS OF PERCEPTION, COGNITION AND EMOTION}

In this paper I describe the process of grammaticalization of Old English causative verbs through the analysis of some of the different strategies for the expression of causation in three different lexical domains: PHYSICAL PERCEPTION, COGNITION and EMOTION. The etymological analysis of these verbs indicates that, in the case of the three lexical domains under scrutiny, causation was lexicalized and conceptualized as forced movement or change of an external (as in the case of verbs of FEELING; e.g. OE hieran 'to hear') or internal (i.e. verbs of COGNITION and some EMOTION verbs; e.g. OE gemynan 'to remember' and OE hiertan 'to encourage') part of the body.

\section{Povzetek \\ IZPELJEVANJE V BESEDNOUTEMELJENI MORFOLOGIJI: O IZVORU STAROANGLEŠKIH GLAGOLOV ZAZNAVE, SPOZNAVANJA IN ČUSTEV}

V pričujočem članku proces gramatikalizacije staroangleških kavzativnih glagolov opisujem s pomočjo analize nekaterih strategij izražanja kavzalnosti na treh različnih leksikalnih ravneh: FIZIČNA ZAZNAVA, SPOZNAVANJE in ČUSTVA. Etimološka analiza teh glagolov pokaže, da je bila v primeru analiziranih leksikalnih področij kavzalnost leksikalizirana in konceptualizirana kot vsiljeno gibanje oziroma sprememba zunanjega (kot na primer pri glagolih oBČUTIJ, npr. staroangleški hieran 'slišati') ali notranjega (na primer glagoli SPOZNAVANJA in nekateri glagoli ČUSTEV, npr. staroangleška gemynan 'spominjati se' in hiertan 'spodbujati') telesnega dela. 